\title{
Nationwide molecular epidemiology of methicillin-resistant Staphylococcus aureus responsible for horse infections in France
}

\author{
François Guérin ${ }^{1,2}$, Marguerite Fines-Guyon², Pierrick Meignen ${ }^{3}$, Géraldine Delente ${ }^{2}$, Caroline Fondrinier ${ }^{1}$, \\ Nancy Bourdon ${ }^{2}$, Vincent Cattoir ${ }^{1,2,5^{*}}$ and Albertine Léon ${ }^{1,4}$
}

\begin{abstract}
Background: The epidemiology of methicillin-resistant Staphylococcus aureus (MRSA) isolated in horse infections is not well documented, especially in France. The aim of the study was to evaluate the prevalence of MRSA isolates in horse infections from 2007 to 2013 in France and to characterize phenotypically and genotypically this collection.

Results: Out of 1393 S. aureus horse isolates, 85 (6.1\%) were confirmed to be MRSA. Interestingly, the prevalence of MRSA significantly increased from 2007-2009 to 2010-2013 (0.7 vs. 9.5\%, $P<0.0001$ ). Resistance to methicillin was due to the presence of the mecA gene in 84 strains (98.8\%) while one strain (1.2\%) possessed the mecC gene. The vast majority of the strains $(83 / 85,97.6 \%)$ was resistant to at least three different classes of antibiotics. Multi-locus sequence typing (MLST) showed that MRSA strains belonged mainly since not all belong to two sequence types (STs): ST398 (53/85, 62.4\%) and ST8 (28/85, 32.9\%). It is worth to note that all ST398 MRSA isolates were detected in the period 2010-2013. Other molecular typing methods were also used, such SCC mec analysis, spa typing and rep-PCR (Diversilab, bioMérieux). All these four techniques were in good agreement, with spa typing and rep-PCR being more discriminative than MLST and SCC $_{\text {mec }}$ typing.

Conclusions: This study is the first epidemiological study in France with extensive characterization of MRSA isolates associated with horse infections in stud farms. It shows that there is a significant increase of MRSA prevalence between 2007 and 2013, which mainly results from the spread of ST398 clones. It also highlights the importance of horses as a potential reservoir of important antimicrobial resistance genes.
\end{abstract}

Keywords: MRSA, Equine infections, ST398, ST8

\section{Background}

Initially reported as a major cause of hospital-acquired infections in humans, methicillin-resistant Staphylococcus aureus (MRSA) has increasingly been reported as responsible for community-acquired infections as well as for infections in animals. Possible transmission of MRSA between humans and animals has raised concern about the role of animals as major reservoirs of MRSA clones

\footnotetext{
* Correspondence: cattoir-v@chu-caen.fr; vincent.cattoir@chu-rennes.fr 'Université de Caen Normandie, EA 4655 (équipe "Antibio-résistance"), F-14032 Caen, France

${ }^{2} \mathrm{CHU}$ de Caen, Service de Microbiologie \& CNR de la Résistance aux Antibiotiques (laboratoire associé "entérocoques et résistances particulières des bactéries à Gram positif"), Av. Côte de Nacre, 14033 Caen, Cedex 9, France

Full list of author information is available at the end of the article
}

involved in human infections [1-4]. Although MRSA strains are usually resistant to $\beta$-lactams through the acquisition of the mecA gene, a homolog gene (called $m e c C$ ) has been recently reported both in animal and human populations [5-7]. It is well known that MRSA is responsible for a large variety of infections in numerous animals; however, specific studies in horses are scarce [6-9]. Indeed, some studies have demonstrated that horses are colonized and infected by MRSA clones that commonly belong to the sequence type (ST) 8 and related STs within the clonal complex (CC)8 $[6,9]$. More recently, studies from Europe and Canada reported horses to be colonized by MRSA clones belonging to ST398, designated livestock-associated (LA)-MRSA, which is primarily recognized as a colonizer of pigs and 
pig farmers [6]. LA-MRSA ST398 can be responsible for infections in humans in close contact with animals. Phenotypically, LA-MRSA ST398 is generally susceptible to antibiotics other than $\beta$-lactams even if it is characteristically resistant to tetracyclines [6]. Note that almost all equine MRSA isolates carry $m e c A$ while $m e c C$ has been rarely detected so far $[6,7]$. From an epidemiological point of view, the prevalence of MRSA in horse infections has been poorly investigated in France $[7,10]$ and most importantly there is no data on nationwide molecular epidemiology.

The aim of the study was then 1) to evaluate the prevalence of MRSA isolated from horse clinical samples recovered between 2007 and 2013 in France, and 2) to extensively characterize phenotypically and genotypically this large collection of equine MRSA strains.

\section{Results}

\section{Prevalence of MRSA isolates}

From 2007 to 2013, the laboratory received 226,878 horse clinical samples with the recovery of 17,651 different bacterial isolates. $S$. aureus was the third most frequent bacterial species isolated $(n=1393 ; 7.9 \%)$ after group C streptococcus $(n=4510 ; 25.6 \%)$ and Escherichia coli $(n=$ 3481; 19.7\%). Out of the 1393 S. aureus horse isolates, 85 (6.1\%) were categorized as MRSA (Table 1). Interestingly, the prevalence of MRSA significantly increased from 20072009 to $2010-2013$ (0.7 vs. 9.5\%, $P<0.0001)$ (Table 1$)$. They were recovered from different sources of infection: skin and soft-tissue $(n=39)$, genital tract $(n=20)$, respiratory tract $(n=8)$, bone and joint $(n=8)$ and others $(n=10)$. Note that MRSA isolates were collected from 56 different stud farms located in 24 different French departments (1 to 24 strains by department), mainly representing the Northwestern parts of France (Fig. 1). This roughly corresponds to the actual geographical distribution of stud farms with a high number of them in Normandy. No isolate harboured $p v l$ and tst toxin genes (data not shown).

Table 1 Prevalence of MRSA from 2007 to 2013

\begin{tabular}{|c|c|c|c|c|c|c|c|c|c|}
\hline \multirow[t]{2}{*}{ Year } & \multirow{2}{*}{$\begin{array}{l}\text { No. of } \\
\text { S. aureus }\end{array}$} & \multirow{2}{*}{$\begin{array}{l}\text { No. of } \\
\text { MRSA }\end{array}$} & \multirow[t]{2}{*}{$\%$ MRSA } & \multicolumn{5}{|c|}{ Type of infection ${ }^{a}$} & \multirow{2}{*}{$\begin{array}{l}\text { \% ST8/ } \\
\text { ST398 }\end{array}$} \\
\hline & & & & $\overline{\text { SSTI }}$ & GTI & RTI & BJ & Others & \\
\hline 2007 & 163 & 2 & $1.2 \%$ & 1 & 0 & 0 & 1 & 0 & $100 / 0$ \\
\hline 2008 & 198 & 2 & $1.0 \%$ & 2 & 0 & 0 & 0 & 0 & $100 / 0$ \\
\hline 2009 & 190 & 0 & $0.0 \%$ & 0 & 0 & 0 & 0 & 0 & - \\
\hline 2010 & 226 & 15 & $6.6 \%$ & 10 & 1 & 1 & 3 & 0 & $53 / 47$ \\
\hline 2011 & 253 & 22 & $8.7 \%$ & 9 & 7 & 2 & 1 & 2 & $14 / 81$ \\
\hline 2012 & 185 & 24 & $12.9 \%$ & 13 & 6 & 3 & 0 & 3 & $40 / 52$ \\
\hline 2013 & 178 & 20 & $11.2 \%$ & 4 & 6 & 2 & 3 & 5 & $15 / 80$ \\
\hline Total & 1393 & 85 & $6.1 \%$ & 39 & 20 & 8 & 8 & 10 & \\
\hline
\end{tabular}

${ }^{a} S S T I$ skin and soft-tissue infection, GTI genital-tract infection, RTI respiratorytract infection, $B J /$ bone and joint infection

${ }^{\mathrm{b}} S T$ sequence type

\section{Antimicrobial resistance profiles}

Resistance to methicillin was associated with the presence of the mecA gene in 84 isolates (98.8\%) while the $m e c C$ gene was detected in only one strain isolated in 2012 (1.2\%) (Table 2). Note that this mecC-positive strain was susceptible to all other antibiotics (Table 2). A vast majority $(83 / 85,97.6 \%)$ were resistant to aminoglycosides with a KTG (kanamycin- tobramycin-gentamicin) phenotype, which was due to the presence of the $\operatorname{aac}\left(6^{\prime}\right)$ $\operatorname{aph}\left(2^{\prime \prime}\right)$ gene in all cases (Table 2). Concerning macrolidelincosamide-streptogramin (MLS) antibiotics, 23 strains (27.1\%) were resistant to erythromycin, most of them (20/ 23) being $\operatorname{erm}(\mathrm{C})$ positive with an inducible $M L S_{\mathrm{B}}$ resistance (Table 2). Almost all strains were resistant to both tested tetracyclines due to the presence of tet $(\mathrm{M})$ only $(81 /$ $85,95.3 \%)$ or both tet $(\mathrm{M})$ and tet $(\mathrm{K})$ genes $(2 / 85,2.3 \%)$ (Table 2). Some strains $(24 / 85,28.2 \%)$ were resistant to fluoroquinolones, including 16 (66.7\%) harbouring mutations in $g y r A$ and/or parC quinolone resistancedetermining regions (QRDRs) and 8 (33.3\%) with putative active efflux (Table 2). Some isolates were categorized as intermediate/resistant to rifampin $(24 / 85,28.2 \%)$, cotrimoxazole $(30 / 85,35.3 \%)$ and chloramphenicol $(23 / 85$, 27.1\%) (Table 2). Finally, all strains remained susceptible to glycopeptides, linezolid and fusidic acid. Note that the vast majority of the strains $(83 / 85,97.6 \%)$ was multiply resistant to at least three different classes of antibiotics.

\section{Analysis of clonal populations}

According to phenotypic and genotypic antimicrobial resistance profiles, 24 different profiles were distinguished (Table 2). MLST revealed that the majority of MRSA isolates belonged to two main STs: ST8 (28/85, 32.9\%) and ST398 (53/85, 62.4\%) (Table 3). Interestingly, all ST398 MRSA isolates were detected in 2010-13 (Tables 1 and 3). By $\mathrm{SCC}_{\text {mec }}$ analysis, the $\mathrm{SCC}_{\text {mec }}$ type IVd was identified in 27/28 (96.4\%) ST8 isolates while the $\mathrm{SCC}_{\text {mec }}$ type IVa found in 52/53 (98.1\%) ST398 isolates (Table 3). The spa typing differentiated the MRSA collection into 15 distinct spa types. The spa types found among the ST8 strains were as follows: t064 $(2 / 28,7.1 \%)$, t394 $(16 / 28$, $57.1 \%), \mathrm{t} 451(3 / 28,10.7 \%), \mathrm{t} 13440(6 / 28,21.4 \%)$ and $\mathrm{t} 5488$ $(1 / 28,3.6 \%)$ (Table 3). Among ST398 strains, the spa type t011 was largely predominant $(44 / 53,83.0 \%)$ followed by t108 (1/53, 1.9\%), t1255 (3/53, 5.7\%), t899 (2/53, 3.8\%), t1451 (1/53, 1.9\%) and t2346 (2/53, 3.8\%) (Table 3). The rep-PCR technique delineated 38 different clusters (using a similarity index of $98.38 \%$ as determined by the Diversilab software) with 66 isolates being grouped in $\geq 2$-isolate clusters and 19 isolates corresponding to singletons (Fig. 1a and Fig. 2a). There was a good agreement between MLST and rep-PCR with the latter method being much more discriminative, especially within the ST398 cluster (Fig. 1b and Fig. 2b). Then, it was possible to 

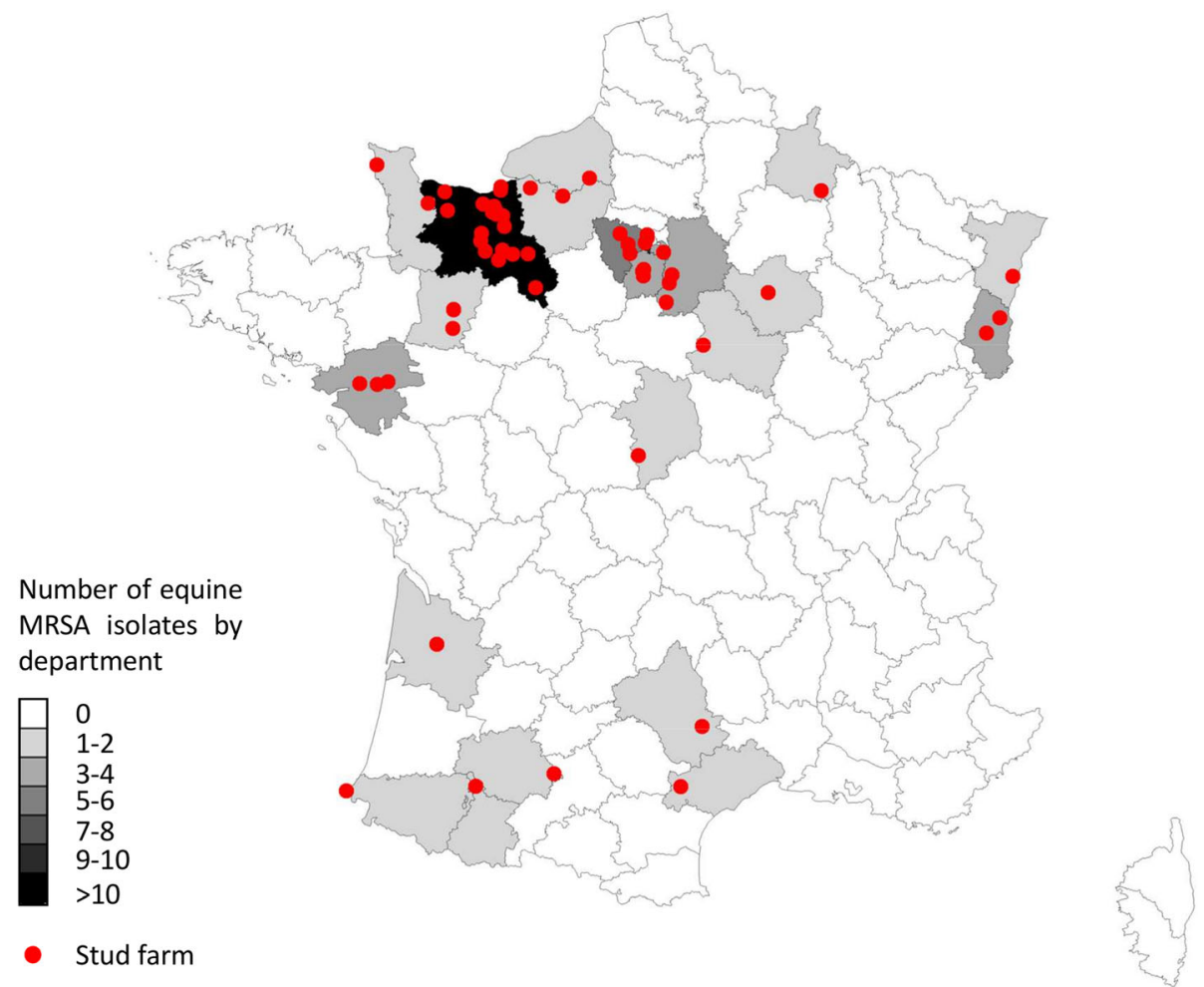

Fig. 1 Map of France representing the distribution of stud farms and the number of MRSA isolates recovered from horses by department. The figure was obtained using the online map tool available at www.lion1906.com/Pages/francais/utile/outils.html\#

distinguish some specific lineages related to certain geographical regions. In addition, rep-PCR had the advantage to dissect the genetic relatedness of ST398 clones since these isolates are not typeable by pulsed-filed gel electrophoresis (PFGE) using SmaI [11].

\section{Discussion}

In this study, we have showed that the prevalence of MRSA strains isolated from horse infections before 2011 was low ( 2\%) in France, with ST8 being predominant during this period. The prevalence has since increased from 2011 to reach about 10\%, and ST398 has become the predominant MRSA lineage. These data on MRSA prevalence in equine infections are in agreement with those observed in other European veterinary hospitals: $22 \%$ in Switzerland [12] and 19\% in Germany [13]. However, it is important to note that MRSA isolates in our study were recovered in stud farms and not in veterinary hospitals. Indeed, the lower prevalence in France observed in our study may be explained by the fact that these samples are from stud farms that are exposed to different environmental conditions and risk factors as compared to veterinary hospitals. Although horses were generally hosted in French stud farms geographically distant, these results suggest a national diffusion of clonally related MRSA ST8 and ST398 isolates.
The mecA-carrying ST8 and ST398 have been reported as the major strains that infected or colonized horses $[13,14]$. Colonization and infection of horses in the USA and Canada generally involve ST8-type MRSA isolates, classified by PFGE as Canadian MRSA-5 or USA500 [6]. ST8 is infrequently found in humans and is among STs isolated from horses of the clonal complex (CC) 8. ST8-type MRSA has also been recently isolated in Australian horses [15]. In France, only one molecular study has been performed on MRSA isolated in horses [10]. In this study, only three MRSA were identified among $59 \mathrm{~S}$. aureus equine isolates and all belonged to the ST8 [10]. ST398-type MRSA is a non-CC8 clone initially report in France in pigs [6], which is currently spreading in horse clinics in Europe and North America $[10,12,16]$. Even if it is characteristically resistant to tetracyclines, this emerging ST is generally susceptible to other antibiotics, which was quite different from what we observed in our study. Indeed, we found that 52 out of 53 (98.1\%) ST398 strains were multiply resistant to at least three classes of antibiotics. Even though multidrug resistance in MRSA is de facto defined as MDR [17], it is important to highlight the very high proportion $(97.6 \%)$ of strains exhibiting resistant to three-toeight antimicrobial categories. Although ST398 is 
Table 2 Antimicrobial resistance profiles and acquired mechanisms of resistance of the 85 MRSA isolates

\begin{tabular}{|c|c|c|c|c|c|}
\hline \multirow[t]{2}{*}{ Antibiotype $^{a}$} & \multirow[t]{2}{*}{$\begin{array}{l}\text { Year of isolation } \\
\text { (number of strains) }\end{array}$} & \multirow[t]{2}{*}{$\begin{array}{l}\text { Antimicrobial resistance } \\
\text { phenotype }^{b, c, d}\end{array}$} & \multirow[t]{2}{*}{ Acquired resistance gene(s) } & \multicolumn{2}{|c|}{$\begin{array}{l}\text { Mutations in } \\
\text { QRDR }\end{array}$} \\
\hline & & & & gyrA & parC \\
\hline 1 & $2012(1)$ & OXA & mecC & & \\
\hline 2 & $2013(1)$ & OXA, TE, MI & $\operatorname{mec} A, \operatorname{tet}(\mathrm{M})$ & & \\
\hline 3 & $2011(1)$ & OXA, K, T, G, CIP & $\operatorname{mec} A, \operatorname{aac}\left(6^{\prime}\right)-\operatorname{aph}\left(2^{\prime \prime}\right)$ & S84L & S80F, E84K \\
\hline $4 a$ & 2010 (1), $2011(2)$ & OXA, K, T, G, CIP, TE, MI & $\operatorname{mec} A, \operatorname{aac}\left(6^{\prime}\right)-\operatorname{aph}\left(2^{\prime \prime}\right), \operatorname{tet}(\mathrm{M})$ & - & - \\
\hline $4 b$ & $2010(1)$ & OXA, K, T, G, CIP, TE, Ml & $m e c A, \operatorname{aac}\left(6^{\prime}\right)-\operatorname{aph}\left(2^{\prime \prime}\right), \operatorname{tet}(\mathrm{M}), \operatorname{tet}(\mathrm{K})$ & - & - \\
\hline 5 & $2011(2), 2012(1)$ & OXA, K, T, G, CIP, TE, MI & $\operatorname{mec} A, \operatorname{aac}\left(6^{\prime}\right)-\operatorname{aph}\left(2^{\prime \prime}\right), \operatorname{tet}(\mathrm{M})$ & S84L & $\mathrm{S} 80 \mathrm{~F}$ \\
\hline 6 & $2010(1)$ & OXA, K, T, G, CIP, TE, MI, RA, SXT & $\operatorname{mec} A, \operatorname{aac}\left(6^{\prime}\right)-\operatorname{aph}\left(2^{\prime \prime}\right), \operatorname{tet}(\mathrm{M})$ & - & - \\
\hline 7 & $2012(1)$ & OXA, K, T, G, CIP, TE, MI, RA, SXT, C & $\operatorname{mec} A, \operatorname{aac}\left(6^{\prime}\right)-\operatorname{aph}\left(2^{\prime \prime}\right), \operatorname{tet}(\mathrm{M})$ & - & $\mathrm{S} 80 \mathrm{~F}$ \\
\hline 8 & $2012(1)$ & OXA, K, T, G, CIP, TE, MI, SXT & $m e c A, \operatorname{aac}\left(6^{\prime}\right)-\operatorname{aph}\left(2^{\prime \prime}\right), \operatorname{tet}(\mathrm{M})$ & S84L & S80F, E84D \\
\hline 9 & $2010(1)$ & OXA, K, T, G, CIP, TE, MI, RA, SXT & $\begin{array}{l}\operatorname{mec} A, \operatorname{aac}\left(6^{\prime}\right)-\operatorname{aph}\left(2^{\prime \prime}\right), \operatorname{aph}\left(3^{\prime}\right)-111 a, \operatorname{ant}\left(4^{\prime}\right)-1 a \\
\operatorname{tet}(\mathrm{M})\end{array}$ & - & - \\
\hline 10 & $2013(1)$ & OXA, K, T, G, E(C), CIP, TE, MI, SXT & $m e c A, \operatorname{aac}\left(6^{\prime}\right)-\operatorname{aph}\left(2^{\prime \prime}\right), \operatorname{tet}(\mathrm{M}), \operatorname{erm}(\mathrm{B})$ & - & - \\
\hline 11 & $2013(1)$ & OXA, K, T, G, E(c), TE, MI, RA, SXT & $\operatorname{mec} A, \operatorname{aac}\left(6^{\prime}\right)-\operatorname{aph}\left(2^{\prime \prime}\right), \operatorname{tet}(\mathrm{M}), \operatorname{erm}(\mathrm{C}), \operatorname{msr}(\mathrm{A})$ & & \\
\hline $12 a$ & $2012(7), 2013(2)$ & OXA, K, T, G, E(i), CIP, TE, MI, RA, SXT, C & $m e c A, \operatorname{aac}\left(6^{\prime}\right)-\operatorname{aph}\left(2^{\prime \prime}\right), \operatorname{tet}(\mathrm{M}), \operatorname{erm}(\mathrm{C})$ & - & $\mathrm{S} 80 \mathrm{~F}$ \\
\hline $12 b$ & $2013(1)$ & OXA, K, T, G, E(i), CIP, TE, MI, RA, SXT, C & $\operatorname{mec} A, \operatorname{aac}\left(6^{\prime}\right)-\operatorname{aph}\left(2^{\prime \prime}\right), \operatorname{tet}(\mathrm{M}), \operatorname{erm}(\mathrm{C}), \operatorname{msr}(\mathrm{A})$ & - & $\mathrm{S} 80 \mathrm{~F}$ \\
\hline 13 & $2013(1)$ & OXA, K, T, G, E(i), TE, Ml & $m e c A, \operatorname{aac}\left(6^{\prime}\right)-\operatorname{aph}\left(2^{\prime \prime}\right), \operatorname{tet}(\mathrm{M}), \operatorname{erm}(\mathrm{C})$ & & \\
\hline 14 & 2007 (2), 2010 (1), 2011 (1) & OXA, K, T, G, E(i), TE, MI, RA, SXT & $m e c A, \operatorname{aac}\left(6^{\prime}\right)-\operatorname{aph}\left(2^{\prime \prime}\right), \operatorname{tet}(\mathrm{M}), \operatorname{erm}(\mathrm{C})$ & & \\
\hline 15 & $2008(1)$ & OXA, K, T, G, E(i), TE, MI, RA, SXT, C & $\operatorname{mec} A, \operatorname{aac}\left(6^{\prime}\right)-\operatorname{aph}\left(2^{\prime \prime}\right), \operatorname{tet}(\mathrm{M}), \operatorname{erm}(\mathrm{C})$ & & \\
\hline 16 & 2010 (3), 2011 (1), 2012 (1) & OXA, K, T, G, E(i), TE, MI, SXT & $\operatorname{mec} A, \operatorname{aac}\left(6^{\prime}\right)-\operatorname{aph}\left(2^{\prime \prime}\right), \operatorname{tet}(\mathrm{M}), \operatorname{erm}(\mathrm{C})$ & & \\
\hline 17 & $2008(1), 2011(1)$ & OXA, K, T, G, E(i), TE, MI, SXT, C & $\operatorname{mec} A, \operatorname{aac}\left(6^{\prime}\right)-\operatorname{aph}\left(2^{\prime \prime}\right), \operatorname{tet}(\mathrm{M}), \operatorname{erm}(\mathrm{C})$ & & \\
\hline 18 & $2010(1)$ & OXA, K, T, G, E, CIP, TE, MI, RA & $\begin{array}{l}\operatorname{mec} A, \operatorname{aac}\left(6^{\prime}\right)-\operatorname{aph}\left(2^{\prime \prime}\right), \operatorname{aph}\left(3^{\prime}\right)-111 \operatorname{l}, \operatorname{tet}(\mathrm{M}) \\
\operatorname{ms} r(\mathrm{~A})\end{array}$ & - & - \\
\hline $19 a$ & $\begin{array}{l}2010 \text { (2), } 2011 \text { (10), } 2012(11), \\
2013(10)\end{array}$ & OXA, K, T, G, TE, Ml & $\operatorname{mec} A, \operatorname{aac}\left(6^{\prime}\right)-\operatorname{aph}\left(2^{\prime \prime}\right), \operatorname{tet}(\mathrm{M})$ & & \\
\hline $19 b$ & $2010(1)$ & OXA, K, T, G, TE, MI & $\operatorname{mec} A, \operatorname{aac}\left(6^{\prime}\right)-\operatorname{aph}\left(2^{\prime \prime}\right), \operatorname{ant}\left(4^{\prime}\right)-\operatorname{la}, \operatorname{tet}(\mathrm{M})$ & & \\
\hline $20 a$ & 2011 (1), 2012 (2), 2013 (2) & OXA, K, T, G, TE, MI, C & $\operatorname{mec} A, \operatorname{aac}\left(6^{\prime}\right)-\operatorname{aph}\left(2^{\prime \prime}\right), \operatorname{tet}(\mathrm{M})$ & & \\
\hline $20 \mathrm{~b}$ & $2013(1)$ & OXA, K, T, G, TE, MI, C & $m e c A, \operatorname{aac}\left(6^{\prime}\right)-\operatorname{aph}\left(2^{\prime \prime}\right), \operatorname{tet}(\mathrm{M}), \operatorname{tet}(\mathrm{K})$ & & \\
\hline 21 & $2010(1)$ & OXA, K, T, G, TE, MI, RA & $m e c A, \operatorname{aac}\left(6^{\prime}\right)-\operatorname{aph}\left(2^{\prime \prime}\right), \operatorname{tet}(\mathrm{M})$ & & \\
\hline 22 & $2010(2)$ & OXA, K, T, G, TE, MI, RA, C & $m e c A, \operatorname{aac}\left(6^{\prime}\right)-\operatorname{aph}\left(2^{\prime \prime}\right), \operatorname{tet}(\mathrm{M})$ & & \\
\hline 23 & $2011(1)$ & OXA, K, T, G, TE, MI, RA, SXT & $\operatorname{mec} A, \operatorname{aac}\left(6^{\prime}\right)-\operatorname{aph}\left(2^{\prime \prime}\right), \operatorname{tet}(\mathrm{M})$ & & \\
\hline 24 & $2012(1)$ & OXA, K, T, G, TE, MI, SXT & $\operatorname{mec} A, \operatorname{aac}\left(6^{\prime}\right)-\operatorname{aph}\left(2^{\prime \prime}\right), \operatorname{tet}(\mathrm{M})$ & & \\
\hline
\end{tabular}

${ }^{2}$ Strains were classified according to their antimicrobial resistance phenotypes (1 to 24). Strains exhibiting identical antimicrobial resistance phenotypes but different genotypes were differentiated as $4 a / 4 b, 12 a / 12 b, 19 a / 19 b$, and 20a/20b

${ }^{b}$ Resistance to: $C$ chloramphenicol, $E$ erythromycin, $G$ gentamicin, $K$ kanamycin, $M I$ minocycline, OXA oxacillin, CIP ciprofloxacin, RA rifampin, SXT cotrimoxazole, TE tetracycline, $T$ tobramycin

${ }^{C} E(i)$, inducible $M L S_{B}$ resistance phenotype; $E(c)$, constitutive $M L S_{B}$ resistance phenotype

${ }^{\mathrm{d}}$ CIP, fluoroquinolone resistance putatively due to an active efflux ( $\geq 2$-fold decrease in MIC of ciprofloxacin in the presence of $10 \mu \mathrm{g} / \mathrm{ml}$ of reserpine)

associated with livestock, sporadic cases, and outbreaks in equine hospitals, colonization of horses and associated personnel have been reported in Europe [6, 11, 18, 19]. Recently, a suspected transmission of MRSA ST398 from a horse to a Dutch girl, which resulted in a foot infection, has been reported [20].

Among other STs, ST612, which belong to the CC8, was recently described in horses and seems to be strongly associated with equine practice veterinarians [21] while ST5, described in pets, swine and poultry [6], was recently reported in horses in Japan [22]. Finally, some authors have recently characterized in animal MRSA isolates belonging to CC130 (ST1245), the most prevalent $\mathrm{CC}$ among $\operatorname{mec} C$-positive strains [7, 23, 24].

\section{Conclusions}

In conclusion, this first epidemiological survey conducted in France has shown an increase in the prevalence of MRSA isolates associated with horse infections since 2010 in stud farms, which is in part related to the emergence of 
Table 3 Comparison of the results obtained by MLST, SCC mec analysis and spa typing for the 85 MRSA horse isolates

\begin{tabular}{llll}
\hline $\begin{array}{l}\text { Year of } \\
\text { isolation }\end{array}$ & $\begin{array}{l}\text { Sequence type } \\
{[S T](\text { no. })}\end{array}$ & spa type (no.) & $\begin{array}{l}\text { SCC mec type } \\
\text { (no.) }\end{array}$ \\
\hline 2007 & $8(2)$ & $\mathrm{t} 394(2)$ & $\mathrm{IVd}(2)$ \\
2008 & $8(2)$ & $\mathrm{t} 064(1), \mathrm{t} 394(1)$ & $\mathrm{IVd}(2)$ \\
2010 & $8(8)$ & $\mathrm{t} 394(1), \mathrm{t} 451(3), \mathrm{t} 5488(1)$, & $\mathrm{II}(1), \mathrm{Vd}(7)$ \\
& $398(7)$ & $\mathrm{t} 13440(3)$ & $\mathrm{IVa}(6), \mathrm{V}(1)$ \\
& & $\mathrm{t} 011(7)$ & \\
2011 & $5(1)$ & $\mathrm{t} 777(1)$ & $\mathrm{VI}(1)$ \\
& $8(3)$ & $\mathrm{t} 394(1), \mathrm{t} 13440(2)$ & $\mathrm{IVd}(3)$ \\
& $398(17)$ & $\mathrm{t} 011(14), \mathrm{t} 1255(2), \mathrm{t} 2346(1)$ & $\mathrm{IVa}(17)$ \\
2012 & $8(10)$ & $\mathrm{t} 064(1), \mathrm{t} 394(8), \mathrm{t} 13440(1)$ & $\mathrm{IVd}(10)$ \\
& $254(1)$ & $\mathrm{t} 009(1)$ & $\mathrm{nt}{ }^{\mathrm{b}}$ \\
& $398(13)$ & $\mathrm{t} 011(10), \mathrm{t} 899(1), \mathrm{t} 1255(1)$, & $\mathrm{IVa}(13)$ \\
& $1245^{\mathrm{a}}(1)$ & $\mathrm{t} 2346(1)$ & $\mathrm{nt}{ }^{\mathrm{b}}$ \\
& & $\mathrm{t} 6220(1)$ & \\
2013 & $8(3)$ & $\mathrm{t} 394(3)$ & $\mathrm{IVd}(3)$ \\
& $398(16)$ & $\mathrm{t} 011(13), \mathrm{t} 108(1), \mathrm{t} 899(1)$, & $\mathrm{IVa}(16)$ \\
& $612(1)$ & $\mathrm{t} 1451(1)$ & $\mathrm{IVd}(1)$ \\
& & $\mathrm{t} 064(1)$ &
\end{tabular}

a mecC-positive strain

${ }^{\mathrm{b}}$ nt not typeable clonally-related ST398 MRSA isolates. Since this new ST398 type is known to cause outbreaks in horses and to colonize/infect humans, hygiene measures and appropriate antimicrobial use should be maintained and reinforced in order to limit the transmission of $S$. aureus between horses as well as between horses and humans.

\section{Methods}

Bacterial isolates and antimicrobial susceptibility testing

The regional veterinary laboratory of Normandy (LABÉO) is specialized in the analysis of specimens from infected horses and receives clinical samples from numerous stud farms located in various regions of France. From January 2007 to December 2013, all non-duplicate clinical isolates of $S$. aureus were prospectively studied.

Over this period, all MRSA horse isolates were further characterized. Species-level identification was performed using the MALDI-TOF mass spectrometry technology (Microflex; Bruker Daltonics, Bremen, France) and, if necessary, by amplification of the S. aureus-specific nuc gene, as previously described [24]. Methicillin resistance
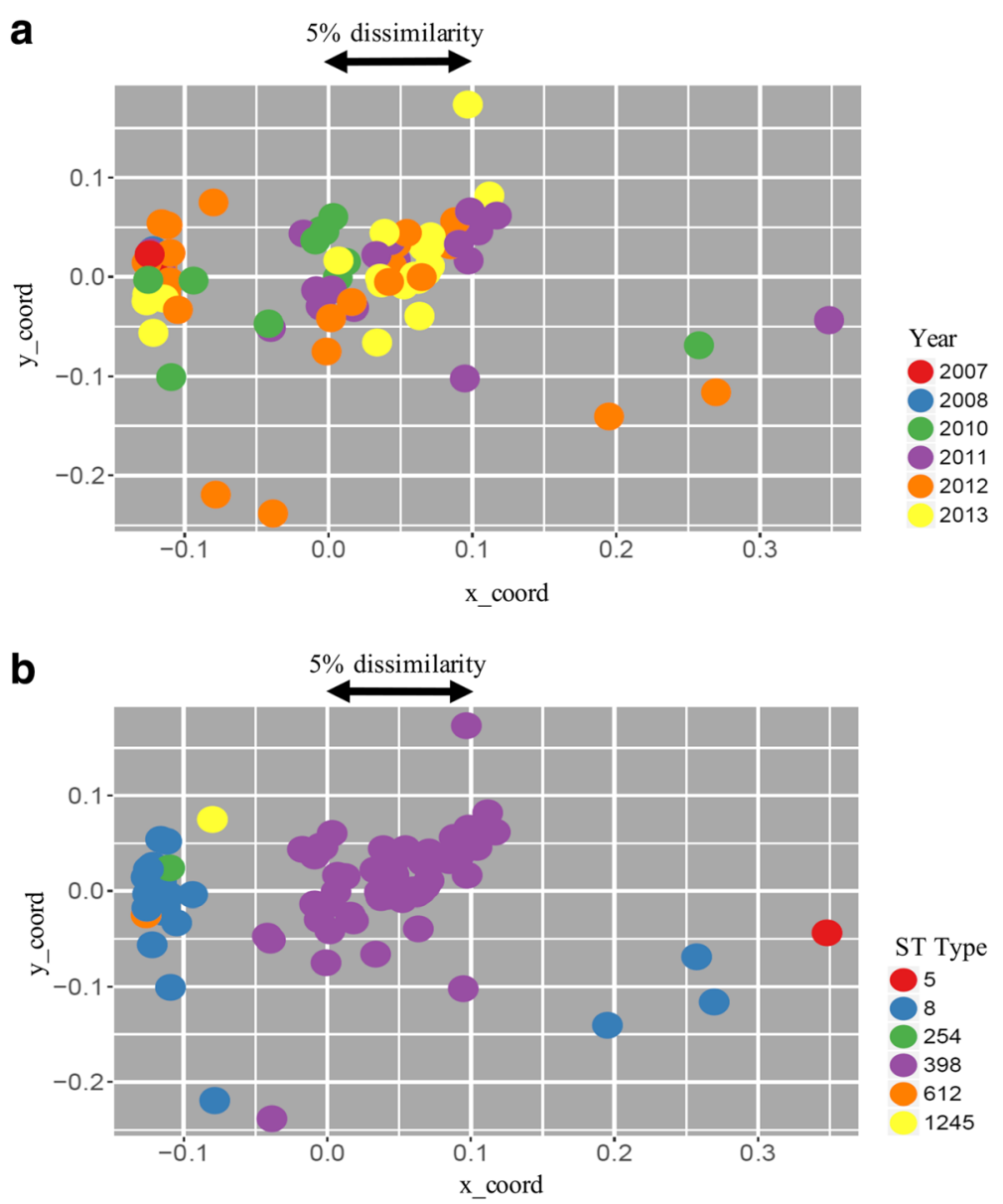

Fig. 2 Scatterplots derived from Diversilab data of the MRSA showing year of isolation (a) and ST type (b). The scale indicates the dissimilarity between strains for the $X$ and $Y$ axes. The graphs were obtained using the using $R$ software and ggplot2 package 
was confirmed by the detection of both $\operatorname{mec} A$ and $m e c C$ genes, as previously described $[5,25,26]$.

Antimicrobial susceptibility testing was performed using the agar diffusion method, as recommended by the Antibiogram Committee of the French Society for Microbiology (www.sfm-microbiologie.org/). The following antibiotics were tested: oxacillin, kanamycin, tobramycin, gentamicin, erythromycin, clindamycin, pristinamycin, ciprofloxacin, vancomycin, teicoplanin, linezolid, tetracycline, minocycline, rifampin, cotrimoxazole, chloramphenicol and fusidic acid. A double-disc diffusion test (D-test) was used to detect the inducible $M L S_{\mathrm{B}}$ resistance phenotype.

\section{PCR and molecular typing}

Genes conferring resistance to MLS [erm(A), erm(B), $\operatorname{erm}(\mathrm{C})$, and $m s r(\mathrm{~A})]$, aminoglycosides [aph(3')-IIIa, $\operatorname{ant}\left(4^{\prime}\right)-I a$, and $\left.\operatorname{aac}\left(6^{\prime}\right)-\operatorname{aph}\left(2^{\prime \prime}\right)\right]$ and tetracyclines [tet $(\mathrm{M})$ and tet $(\mathrm{K})$ ] were screened by PCR, as previously described [27-29]. Mechanisms of fluoroquinolone resistance were studied by sequencing QRDRs of gyrA and parC genes [30] and by determining MICs of ciprofloxacin with or without reserpin $(10 \mu \mathrm{g} / \mathrm{ml})$. Both $p v l$ and $t s t$ genes coding for Panton-Valentine leukocidin (PVL) and toxic shock staphylococcal toxin (TSST-1), respectively, were screened by PCR as previously described [31-33].

For molecular typing, four different techniques were used for all the strains. The MLST was performed as previously described [34] using the MLST database (http://saureus.mlst.net/). The spa typing was carried out as previously described [35] using the Ridom StaphType software (Ridom $\mathrm{GmbH}$, Würzburg, Germany). The typing of staphylococcal cassette chromosome mec element (SCCmec) was performed according to mec and $c c r$ complexes previously defined [36]. Genetic relatedness was determined by rep-PCR using the semi-automated Diversilab system (bioMérieux, Marcy l'étoile, France) [14, 37].

\section{Statistical analysis}

The Fisher's exact test was used to compare categorical variables. $P$ values $<0.05$ were considered to be statistically significant. All tests were 2 tailed. Statistical tests were performed using GraphPad Prism, version 6.

\begin{abstract}
Abbreviations
CC: Clonal complex; MALDI-TOF: Matrix-assisted laser desorption/ionizationtime-of-flight; MIC: Minimal inhibitory concentration; MLS: Macrolideslincosamides-streptogramins; MLST: Multi-locus sequence typing; MRSA: Methicillin-resistant Staphylococcus aureus; PFGE: Pulsed-field gel electrophoresis; PVL: Panton-Valentine leucocidin; QRDR: Quinolone-resistance determining region; SCCmec: Staphylococcal cassette chromosome mec element; ST: Sequence type; TSST-1: Toxic shock staphylococcal toxin
\end{abstract}

\section{Acknowledgments}

We warmly thank Prof. H. de Lencastre (Universidade Nova de Lisboa, Portugal) for providing control strains of MRSA.

\section{Funding}

This work was supported by grants from Conseil Départemental du Calvados to LABÉO Frank Duncombe and from Ministère de l'Enseignement Supérieur et de la Recherche to EA4655, Normandie Université, France.

\section{Availability of data and materials}

All data and materials are available in the research group EA 4655 (team "Antibioresistance"), University of Caen Normandie, F-14032 Caen, France.

\section{Authors' contributions}

FG, MFG, VC and AL conceived and designed the experiments. FG, MFG, PM, $\mathrm{GD}, \mathrm{CF}$ and NB performed the experiments. FG, MFG, PM, VC and AL analyzed the data. FG, VC and AL wrote the paper. All authors read and approved the final manuscript.

\section{Competing interests}

The authors declare that they have no competing interests.

\section{Consent for publication}

Not applicable.

\section{Ethics approval and consent to participate}

Not applicable.

\section{Author details}

'Université de Caen Normandie, EA 4655 (équipe "Antibio-résistance"), F-14032 Caen, France. ${ }^{2} \mathrm{CHU}$ de Caen, Service de Microbiologie \& CNR de la Résistance aux Antibiotiques (laboratoire associé "entérocoques et résistances particulières des bactéries à Gram positif"), Av. Côte de Nacre, 14033 Caen, Cedex 9, France. ${ }^{3}$ Université de Caen Normandie, IUT département STID, F-14033, Caen, France. ${ }^{4}$ LABÉO Frank Duncombe, F-14053, Caen, France. ${ }^{5} \mathrm{CHU}$ de Rennes, Service de Bactériologie-Hygiène hospitalière, Hôpital Pontchaillou, 2 rue Henri Le Guilloux, 35033 Caen, Cedex 9, France.

Received: 5 October 2016 Accepted: 28 December 2016

Published online: 03 May 2017

\section{References}

1. Cefai C, Ashurst S, Owens C. Human carriage of methicillin-resistant Staphylococcus aureus linked with pet dog. Lancet. 1994;344:539-40.

2. Manian FA. Asymptomatic nasal carriage of mupirocin-resistant, methicillinresistant Staphylococcus aureus (MRSA) in a pet dog associated with MRSA infection in household contacts. Clin Infect Dis. 2003;36:e26-8.

3. O'Mahony R, Abbott Y, Leonard FC, Markey BK, Quinn PJ, Pollock PJ, Fanning S, Rossney AS. Methicillin-resistant Staphylococcus aureus (MRSA) isolated from animals and veterinary personnel in Ireland. Vet Microbiol. 2005;109:285-96.

4. van Duijkeren E, Wolfhagen MJ, Box AT, Heck ME, Wannet WJ, Fluit AC. Human-to-dog transmission of methicillin-resistant Staphylococcus aureus. Emerg Infect Dis. 2004;10:2235-7.

5. García-Álvarez L, Holden MT, Lindsay H, Webb CR, Brown DF, Curran MD, Walpole E, Brooks K, Pickard DJ, Teale C, et al. Meticillin-resistant Staphylococcus aureus with a novel mecA homologue in human and bovine populations in the UK and Denmark: a descriptive study. Lancet Infect Dis. 2011;11:595-603.

6. Pantosti A. Methicillin-resistant Staphylococcus aureus associated with animals and its relevance to human health. Front Microbiol. 2012;3:127.

7. Haenni M, Châtre P, Dupieux C, Métayer V, Maillard K, Bes M, Madec JY, Laurent F. mecC-positive MRSA in horses. J Antimicrob Chemother. 2015;70:3401-2.

8. Shimizu A, Kawano J, Yamamoto C, Kakutani O, Anzai T, Kamada M. Genetic analysis of equine methicillin-resistant Staphylococcus aureus by pulsed-field gel electrophoresis. J Vet Med Sci. 1997;59:935-7.

9. Carfora V, Caprioli A, Grossi I, Pepe M, Alba P, Lorenzetti S, Amoruso R, Sorbara L, Franco A, Battisti A. A methicillin-resistant Staphylococcus aureus (MRSA) Sequence Type 8, spa type t11469 causing infection and colonizing horses in Italy. Pathog Dis. 2016;74:ftw025.

10. Haenni M, Targant H, Forest K, Sévin C, Tapprest J, Laugier C, Madec JY. Retrospective study of necropsy-associated coagulase-positive staphylococci in horses. J Vet Diagn Invest. 2010;22:953-6.

11. Grisold AJ, Zarfel G, Hoenigl M, Krziwanek K, Feierl G, Masoud L, Leitner E, Wagner-Eibel U, Badura A, Marth E. Occurrence and genotyping using 
automated repetitive-sequence-based PCR of methicillin-resistant Staphylococcus aureus ST398 in Southeast Austria. Diagn Microbiol Infect Dis. 2010;66:217-21.

12. Sieber S, Gerber V, Jandova V, Rossano A, Evison JM, Perreten V. Evolution of multidrug-resistant Staphylococcus aureus infections in horses and colonized personnel in an equine clinic between 2005 and 2010. Microb Drug Resist. 2011:17:471-8.

13. Cuny C, Witte W. MRSA in equine hospitals and its significance for infections in humans. Vet Microbiol. 2017;200:59-64.

14. Loncaric I, Künzel F, Licka T, Simhofer H, Spergser J, Rosengarten R. Identification and characterization of methicillin-resistant Staphylococcus aureus (MRSA) from Austrian companion animals and horses. Vet Microbiol. 2014;168:381-7.

15. Tenover FC, Gay EA, Frye S, Eells SJ, Healy M, McGowan Jr JE. Comparison of typing results obtained for methicillin-resistant Staphylococcus aureus isolates with the Diversilab system and pulsed-field gel electrophoresis. J Clin Microbiol. 2009:47:2452-7.

16. van Duijkeren $E$, Ten Horn L, Wagenaar JA, de Bruijn M, Laarhoven L, Verstappen K, de Weerd W, Meessen N, Duim B. Suspected horse-to-human transmission of MRSA ST398. Emerg Infect Dis. 2011;17:1137-9.

17. Magiorakos AP, Srinivasan A, Carey RB, Carmeli Y, Falagas ME, Giske CG, Harbarth S, Hindler JF, Kahlmeter G, Olsson-Liljequist B, et al. Multidrugresistant, extensively drug-resistant and pandrug-resistant bacteria: an international expert proposal for interim standard definitions for acquired resistance. Clin Microbiol Infect. 2012;18:268-81.

18. Axon JE, Carrick JB, Barton MD, Collins NM, Russell CM, Kiehne J, Coombs G. Methicillin-resistant Staphylococcus aureus in a population of horses in Australia. Aust Vet J. 2011;89:221-5.

19. Van den Eede A, Martens A, Lipinska U. High occurrence of methicillin-resistant Staphylococcus aureus ST398 in equine nasal samples. Vet Microbiol. 2009;133:138-44.

20. van Duijkeren E, Moleman M, Sloet van Oldruitenborgh-Oosterbaan MM, Multem J, Troelstra A, Fluit AC. Methicillin-resistant Staphylococcus aureus in horses and horse personnel: an investigation of several outbreaks. Vet Microbiol. 2010;141:96-102.

21. Groves MD, Crouch B, Coombs GW, Jordan D, Pang S, Barton MD, Giffard P, Abraham S, Trott DJ. Molecular Epidemiology of methicillin-resistant Staphylococcus aureus isolated from Australian veterinarians. PLoS One. 2016;11:e0146034.

22. Kuroda T, Kinoshita Y, Niwa H, Shinzaki Y, Tamura N, Hobo S, Kuwano A Meticillin-resistant Staphylococcus aureus colonisation and infection in Thoroughbred racehorses and veterinarians in Japan. Vet Rec. 2016;178:473.

23. Haenni M, Châtre P, Tasse J, Nowak N, Bes M, Madec JY, Laurent F. Geographical clustering of mecC-positive Staphylococcus aureus from bovine mastitis in France. J Antimicrob Chemother. 2014;69:2292-3.

24. Porrero MC, Harrison EM, Fernández-Garayzábal JF, Paterson GK, Díez-Guerrier A, Holmes MA, Domínguez L. Detection of mecC-Methicillin-resistant Staphylococcus aureus isolates in river water: a potential role for water in the environmental dissemination. Environ Microbiol Rep. 2014;6:705-8.

25. Cattoir V, Merabet L, Djibo N, Rioux C, Legrand P, Girou E, Lesprit P. Clinical impact of a real-time PCR assay for rapid identification of Staphylococcus aureus and determination of methicillin resistance from positive blood cultures. Clin Microbiol Infect. 2011;17:425-31.

26. Stegger M, Andersen PS, Kearns A, Pichon B, Holmes MA, Edwards G, Laurent F, Teale C, Skov R, Larsen AR. Rapid detection, differentiation and typing of methicillin-resistant Staphylococcus aureus harbouring either mecA or the new mecA homologue mecA(LGA251). Clin Microbiol Infect. 2012:18:395-400.

27. Le Bouter A, Leclercq R, Cattoir V. Molecular basis of resistance to macrolides, lincosamides and streptogramins in Staphylococcus saprophyticus clinical isolates. Int J Antimicrob Agents. 2011;37:118-23.

28. Udo E, Dashti A. Detection of genes encoding aminoglycoside-modifying enzymes in staphylococci by polymerase chain reaction and dot blot hybridization. Int J Antimicrob Agents. 2000;13:273-9.

29. Leclercq R, Oberlé K, Galopin S, Cattoir V, Budzinski H, Petit F. Changes in enterococcal populations and related antibiotic resistance along a medical center-wastewater treatment plant-river continuum. Appl Environ Microbiol. 2013;79:2428-34.

30. Trong HN, Prunier AL, Leclercq R. Hypermutable and fluoroquinoloneresistant clinical isolates of Staphylococcus aureus. Antimicrob Agents Chemother. 2005;49:2098-101.

31. Oliveira DC, de Lencastre H. Multiplex PCR strategy for rapid identification of structural types and variants of the mec element in methicillin-resistant Staphylococcus aureus. Antimicrob Agents Chemother. 2002;46:2155-61.
32. Nhan TX, Leclercq $R$, Cattoir V. Prevalence of toxin genes in consecutive clinical isolates of Staphylococcus aureus and clinical impact. Eur J Clin Microbiol Infect Dis. 2011;30:719-25.

33. Lina $G$, Piémont $Y$, Godail-Gamot $F$, Bes $M$, Peter $M O$, Gauduchon $V$, Vandenesch F, Etienne J. Involvement of Panton-Valentine leukocidinproducing Staphylococcus aureus in primary skin infections and pneumonia. Clin Infect Dis. 1999;29:1128-32.

34. Enright MC, Day NP, Davies CE, Peacock SJ, Spratt BG. Multilocus sequence typing for characterization of methicillin-resistant and methicillin-susceptible clones of Staphylococcus aureus. J Clin Microbiol. 2000;38:1008-15.

35. Strommenger B, Kettlitz C, Weniger T, Harmsen D, Friedrich AW, Witte W. Assignment of Staphylococcus isolates to groups by spa typing, Smal macrorestriction analysis, and multilocus sequence typing. J Clin Microbiol. 2006;44:2533-40.

36. Zhang K, McClure JA, Elsayed S, Louie T, Conly JM. Novel multiplex PCR assay for characterization and concomitant subtyping of staphylococcal cassette chromosome mec types I to V in methicillin-resistant Staphylococcus aureus. J Clin Microbiol. 2005;43:5026-33.

37. Te Witt R, Kanhai $V$, van Leeuwen WB. Comparison of the DiversiLab system, pulsed-field gel electrophoresis and multi-locus sequence typing for the characterization of epidemic reference MRSA strains. J Microbiol Methods. 2009;77:130-3.

\section{Submit your next manuscript to BioMed Central and we will help you at every step:}

- We accept pre-submission inquiries

- Our selector tool helps you to find the most relevant journal

- We provide round the clock customer support

- Convenient online submission

- Thorough peer review

- Inclusion in PubMed and all major indexing services

- Maximum visibility for your research

Submit your manuscript at www.biomedcentral.com/submit
C) Biomed Central 